\title{
PENGARUH SISTEM INFORMASI MANAJEMEN DALAM MENINGKATKAN EFEKTIVITAS DAN EFISIENSI PENGELOLAAN SEKOLAH
}

\author{
Putri Ramadhani \\ 17002026
}

Email atiputrirmd99@gmail.com

\begin{abstract}
ABSTRAK
Sekolah atau lembaga pendidikan tentunya memerlukan yang namanya manajemen. Layaknya sebuah perusahaan sekolah atau lembaga pendidikan mempunyai pimpinan, karyawan, pelanggan serta produk yang dihasilkan. Tentunya semua itu memerlukan manajemen yang baik, terarah dan terencana. Pada zaman sekarang ini teknologi berkembang pesat. Hal itu ternyata juga berdampak pada manajemen sekolah. Banyak sekolah yang sudah memanfaatkan teknologi informasi dalam manajemennya. Sehingga sekarang ini banyak sekolah yang sudah menerapkan sistem informasi manajemen dalam lembaganya. Lembaga pendidikan harus menetapkan visi dan misi yang jelas untuk menciptakan keputusan yang berkualitas dan beroperasi sesuai dengan perkembangan zaman. Untuk mewujudkannya perlu dibuat suatu struktur dan manajemen yang pasti dan sesuai dengan visi dan misi lembaga pendidikan. Melalui penggunaan internet dan sistem informasi lembaga pendidikan dapat mengembangkan manajemen yang baik. Sistem informasi manajemen menyediakan informasi bagi para pegelolaan pendidikan untuk pengambilan keputusan. Sistem informasi manajemen menyediakan strategis yang diperlukan untuk menentukan langkah pendidikan. Sistem informasi manajemen akan sangat membantu para pengelolaan pendidikan dari berbagai tingkatan dalam menentukan tugasnya.
\end{abstract}

Kata kunci : Manajemen, Lembaga Pendidikan, Sistem Informasi Manajemen

\section{LATAR BELAKANG}

Sistem adalah sekumpulan elemen-elemen yang saling berinteraksi dan bekerja sama untuk mencapai tujuan tertentu. Informasi adalah data yang telah diolah sehingga dapat bermanfaat bagi penggunanya. Sistem informasi manajemen adala suatu sistem yang diperlikan o; eh suatu organisasi untuk menyediakan informasi yang penting dalam rangka mencapai tujuan organisasi.

Tujuan sistem informasi manajemen diantaranya :

- Mempermudah proses pengelolaan data akademik dan non akademik sekolah.

- Menjadi panduan untuk membuat membuat peraturan sekolah.

- Berpean sebagai sarana komunikasi masyarakat dan orang tua siswa tanpa batasan waktu dan tempat.

- Menyediakan suatu laporan perkembangan siswa dalam proses pengajaran.

- Menjadikan media promosi sekolah.

- Mempermudah orang tua dalam memonitor perkembangan anakanya disekolah.

- Membantu siswa dalam persiapan sebelum memasuki jenjang pendidikan selanjutnya 
- Menyediakan suatu media bagi siswa untuk memantau perkembangan baik dari sisi akademik maupun non akademik.

- Membantu siswa dalam memperoleh informasi mengenai mata pelajaran sekolah dan meningkatkan prestasi siswa melalui data base bahan pelajaran soal dan latihan.

Seiring berkembangnya zaman dan teknologi hal ini juga mendukung perkembangan sistem informasi manajemen menjadi semakin meningkat. Seperti pada saat sekarang ini sudah banyak sekolah yang menggunakan pendaftaran sistem online. Dimana sistem ini memudahkan calon siswa utuk mendaftar kesekolah tersebut. Calon siswa hanya perlu memasukkan syarat-syr berkas yang harus dipenuhi, dan dari pihak sekolah dapat dengan mudah menyeleksi data dari siswa yang persyaratannya tepenuhi.

Manfaat sistem informasi manajemen dalam dunia pendidikan juga mencakup banyak sektor diamtaranya :

a. Hal koneksi dan setting

b. Pengelolaan kesiswaan

c. Pengelolaan akademik

d. Pengelolaan data guru dan karyawan

e. Pengelolaan keuangan sekolah

f. Pengelolaan dan penertiban administrasi perpustakaan

g. Bank soal

\section{PEMBAHASAN}

Menurut Ahmad Sabandi dalam jurnalnya (Sabandi, 2019) berpendapat bahwa sistem informasi manajemen adalah suatu metode untuk menghasilkan informasi yang tepat waktu bagi manajemen tentang lingkungan luar organisasi, dengan tujuan untuk menunjang proses pengambilan keputusan serta memperbaiki proses perencanaan dan pengawasan. Oleh karena itu dengan adanya sistem informasi manajemen sekolah mampu memeprmudah kinerja guru untuk menghasilakan mutu pendidikan yang lebih berkuaalitas lagi. Sistem informasi manajemen merupakan sebuah sistem yang terdiri dari beberapa elemen/komponen yang saling berkaitan satu dengan yang lainnya.

Elemen/komponen dari sebuah sistem ini tentu saja akan saling terkoordinasi dengan baik agar dapat mencapai tujuan yang ingin dicapai. Secara sederhana sistem informasi memiliki 3 kegiatan utuama didalamnya yaitu menerima data sebagai masukan kemudian data tersebut di proses dengan melakukan perhitungan, penggabungan unsur data, dan pemutakhiran akun, setelah itu akan mendapatkan informasi sebagai keluaran.

Sistem informasi manajemen sekolah merupakan perpaduan antara sumber daya manusisa dan aplikasi teknologi informasi untuk memilih, menyimpan, mengolah dan mengambil kembali data dalam rangka mendudkung kembali proses pengambilan keputusan bidang pendidikan. Yang bertujuan sebagai upaya menfasilitasi siswa dalam membuat, memonitor, dan mengelola rencana pendidikan, karir, dan pengembangan sosial pribadi oeh dirirnya. Berikut pengaruh SIM dalam pengeloaan sekolah diantaranya :

a. Dapat mempermudah proses pendjadwalan

b. Memperkenalkan dunia IT secara dini terhadap siswa

c. Pengelolaan kepegawaian akan semakin mudah

d. Informasi alumni, siswa yang lulus, siswa DO, siswa meninggal, akan tercatat datanya 
e. Kepala sekolah akan lebih mudah menyusun rencana jangka pendek, jangka panjang untuk meningkatkan mutu sekolah

f. Mempermudah dalam proses nilai

g. Wali kelas akan dapat lebih cepat mengontrol hasil belajar siswanya secara mudah dan cepat

h. Proses penerimaan siswa baru semakin cepat dan akurat

i. Mempermudah penyusunan laporan sekolah

Menurut wiyardi dalam jurnalnya (Wiyardi, 2016) berpendapat bahwa untuk memperoleh informasi yang realibel, valid, terkini, sekolah memerlukan sebuah jenis sistem formal dalam sekolahnya yang dapat mengelola data informasi yang ada. Sistem informasi manajemen daoat dikelola oleh tenaga administrasis sekolah dibawah koordinasi kepala sekolah untuk sekolah-sekolah yang ada di Indonesia. SIM akan membantu kepala sekolah yang ada dalam mengambil keputusan terkait dengan langkah-langkah strategis sekolah termasuk didalamnya formulais rencana strategik.

Menurut Ahmad Sabandi dalam jurnalnya (Sabandi, 2019) berpendapat bahwa proses merupakan bagian yang memerlukan perubahan atau transformasi dari masukan menjadi keluaran yang berguna. Untuk mendapatkan keluaran yang berguna bagi pengguna sistem informasi manajemen akademik sekolah tentu saja pada saat proses mengubah masukan menjadi keluaran harus dilakukan sebaik mungkin. Oleh karena itu pada aktivitas pross ada beberap hal yang harus dilakukan yaitu :

1. Pengelolaan data

2. Penyimpanan data

Pada era globalisasi sistem informasi semakin dibutuhkan oleh lembaga pendidikan khususnya dalam meningkatkan kelancaran aliran informasi dalam lembaga pendidikan, kontrol kualitas, dan menciptakan aliansi atau kerja sama dengan pihak lain yang dapat meningkatkan nilai lembaga pendidikan tersebut. Dengan adanya SIM di harapkan dapat membantu kepala sekolah dalam mengelola manajemen sekolah serta mengambil keputusan dan kebijakan. Hal ini karena SIM mempunyai keunggulan dapat memproses informasi SIM juga dapat mengontrol setiap kinerja manajemen sekolah dan membantu merencanakan tentang kinerja manajemen sekolah. Sehingga kinerja manajemen sekolah menjadi cepat dan produktifitas sekolah juga meningkat.

Menurut Tri Firmansyah dkk dalam jurnalnya (Tri, 2017) berpendapat bahwa sistem informasi manajemen mempunyai peran dalam meningkatkan tugas guru karena dapat mempercepat guru untuk menyampaikan materi ke siswa serta membuat perangkat laporan siswa. Karena dalam sistem informasi manajemen sistem basis data menjadi satu, dalam sistem tersebut dipisahkan sesuai dengan jenis data yang dimasukkan. Dari data tersebutlah informasi yang akan di sampaikan lebih cepat, efektif dan efisien.

Menurut Siti Nur Elia Lailasari dalam jurnalnya (siti nur elia, 2017) berpendapat bahwa Mendapatkan informasi yang akurat dari sekolah adalah salah satu kepuasan yang ingin didapatkan oleh peserta didik. Karena itulah sekolah membutuhkan proses manajamen untuk memenuhi kebutuhan akan informasi tersebut. Proses manajemerial pada hakikatnya adalah sebuah proses pengambilan keputusan akan suatu hal di lembaga pendidikan. Sebuah proses pengambilan keputusan haruslah didukung oleh sebuah sistem pengambilan keputusan yang dapat memanfaatkan media informasi yang ada. Sistem informasi manajemen dapat diajadikan alternatif pilihan untuk meningkatkan kualitas lembaga pendidikann dalam menyajikan aktivitas secara lebih cepat. 


\section{KESIMPULAN DAN SARAN}

Penggunaan sistem informasi manajemen menunjukkan efek positif terhadap lembaga pendidikan sekolah tidak hanya dalam ruang lingkup nasional melainkan juga internasional dikarenakan penggunaan teknologi terbaru identik penyesuaiananya dengan standar yang digunakan di berbagai negara. Sistem informasi manajemen sekolah ini berkaitan dengan tenaga pengajar sekolah. Isinya antara lain pengelolaan penerimaan pegawai, mengenai jumlah tenaga pengajar, dan evaluasi kemampuan tenaga belajar serta data administrasi sekolah. Sistem informasi manajemen merupakan media untuk menghubungkan berbagai pihak baik pihak dari dalam sekolah maupun luar sekolah. Hal ini bertujuan utuk menyediakan suatu layanan informasi mengenai sekolah serta menjelaskan berbagai hubungan pihak lain untuk membagikan ide dan gagasan yang berkaitan dengan sekolah.

Sistem yang di anggap layak secara operasional juga dilihat sejauah mana kemapuan pihak sekolah baik staff sekolah, guru, siswa, oranh tua siswa dan masyarakat dalam menggunakannya. Jika mereka mampu memahami penggunaan setiap bagian sistem maka sistem informasi manajemen dapat beroperasi dengan baik dan dapat meningkatkan efektifitas dan efisiensi pengelolaan sekolah. 


\section{DAFTAR RUJUKAN}

Sabandi, A. (2019). PERSEPSI GURU DALAM MENINGKATKAN MUTU PENDIDIKAN ANAI, SISTEM INFORMASI MANAJEMEN DI SEKOLAH DASAR NEGERI 08 BATANG. Jurnal Pendidikan, 2(3).

Sabandi, A. (2019). PERSEPSI GURU TERHADAP PENERAPAN SISTEM INFORMASI MANAJEMEN AKADEMIK DI SEKOLAH MENENGAH KEJURUAN (SMK) NEGERI 3 PADANG. Jurnal Bahana Manajemen Pendidikan, 8(1), 1-8.

siti nur elia, L. (2017). SISTEM INFORMASI MANAJEMEN SEKOLAH DAN BUDAYA SEKOLAH TERHADAP KEPUASAN SISWA SMAN DI KOTA BANDUNG. Jurnal Pendidikan, 2(2).

Tri, F. dk. (2017). HUBUNGAN PENGELOLAAN SISTEM INFORMASI MANAJEMEN DENGAN PRODUKTIFITAS GURU SMK. Jurnal Teknologi Elektro, 8(2), 101-108.

Wiyardi. (2016). KEPEMIMPINAN KEPALA SEKOLAH, SISTEM INFORMASI MANAJEMEN, DAN FORMULASI RENCANA STRATEGIS. Jurnal Administrasi Pendidikan, 23(2). 